\title{
Effect of Dietary Supplementation of Germinated Maize on Hematological Parameters of Kadaknath Layers
}

\section{Akhelesh Kumar Karoriya, Archana Jain*, Chouhan Laxmi, MK. Mehta and Rakesh Kumar}

Department of Veterinary Physiology and Biochemistry, College of Veterinary Science and A. H., NDVSU, Mhow, MP, India

*Corresponding Author: Archana Jain, Department of Veterinary Physiology and Biochemistry, College of Veterinary Science and A. H., NDVSU, Mhow, MP, India.

DOI: $10.31080 /$ ASVS.2020.02.0079

\section{Abstract}

The present research work was undertaken to find out the effect of supplementation of germinated maize at different levels on hematological parameters of Kadaknath layers started from day old stage. The experiment was done on a total number of 128 , day old chicks (DOC) of Kadaknath breed belonging to same hatch. On arrival, the chicks were weighed and equally distributed randomly into four treatment groups T0, T1, T2 and T3 with 32 chicks each. Each group was divided into four replicates of 8 chicks each. The control group T0 was given commercial maize - DOC soya based diet. The treatment groups T1, T2 and T3 were given diet containing germinated maize at $50 \%, 75 \%$ and $100 \%$ levels of the cereal component, respectively. The experimental chicks were vaccinated against the prescribed schedule of vaccination. All the chicks were housed in deep litter system in the well ventilated and lighted rooms and the feed was given ad lib with plenty of fresh water.

Five birds were separated from each group on 30 days, 60, 90, 120, 150, 180, 210 and 240 days for collection of about 2 - 3 ml of blood in EDTA and non EDTA vials for hematological analysis.

All observations were analyzed by using ANOVA to compare different treatment groups. There were a significant $(\mathrm{P}<0.01, \mathrm{P}<$ 0.05 ) increase in all hematological parameters such as total erythrocyte count, total leukocyte count, hemoglobin, packed cell volume, mean corpuscular volume, mean corpuscular hemoglobin and mean corpuscular hemoglobin concentration in all the treated groups as compared to control from values taken every 30 days up to 240 days of age.

Keywords: Dietary Supplementation; Germinated Maize; Kadaknath Layers

\section{Introduction}

Poultry keeping is practiced by majority of the poor and marginalized rural households all over India. These households rely on low cost backyard poultry rearing to supplement and enhance their livelihoods. It is only recently that the Government of India has recognized the potential of small-scale poultry sector development for poverty reduction. This will initiate projects to promote new areas of indigenous backyard poultry farming of Kadaknath. It is being reared by tribal communities in its breeding tract of the Jhabua and Dhar districts in the western region of the state of Madhya Pradesh and in adjoining areas of the states of Gujarat and Rajasthan.
Kadaknath is an important Indian poultry breed, also known as Kalamashi in Hindi, is known for its black-colored meat, poor egg production, slow growth rate, smaller body size as well as late sexual maturity. The commonly available colours of Kadaknath are jetblack, penciled and golden. In all the three varieties of Kadaknath breed, most of the internal organs exhibit intense black coloration which is due to the deposition of melanin pigment in the connective tissue of organs and in the dermis. The flesh of this breed is black, it is considered not only for the delicacy of distinctive taste and flavor, but also of medicinal value. The meat and eggs are considered rich sources of protein and iron. Kadaknath needs to be systematically evaluated for its medicinal value for the treatment of many diseases. 
Sprouting of grains can be used advantageously as it has resulted in increase in quantity as well as in quality of certain enzyme activities, protein, sugars, minerals and vitamins.

This type of work has not been done in M.P and India in Kadaknath layers so this work will be under taken to explore the egg production capabilities of Kadaknath birds supplemented with germinated maize without any added cost.

\section{Materials and Methods}

A total number of 128, day old chicks (DOC) of Kadaknath breed belonging to same hatch were used for the experiment. On arrival, the chicks were weighed and equally distributed randomly into four treatment groups T0, T1, T2 and T3 of 32 chicks. Each group was divided into four replicates of 8 chicks each with the duration of the experiment was 8 month. The control group T0 was given commercial maize - DOC soya based diet. The treatment groups $\mathrm{T} 1, \mathrm{~T} 2$ and $\mathrm{T} 3$ were given diet containing germinated maize at $50 \%, 75 \%$ and $100 \%$ levels of the cereal component, respectively. The experimental chicks were vaccinated against the prescribed schedule of vaccination. All the chicks were housed in deep litter system in the well ventilated and lighted rooms and the feed was given ad lib with plenty of fresh water.

\begin{tabular}{|l|c|c|c|c|}
\hline $\begin{array}{c}\text { Sr. } \\
\text { No. }\end{array}$ & Treatment group & $\begin{array}{c}\text { No. of birds/ } \\
\text { pen/ replica- } \\
\text { tion }\end{array}$ & $\begin{array}{c}\text { No. of } \\
\text { repli- } \\
\text { cation }\end{array}$ & $\begin{array}{c}\text { Total num- } \\
\text { ber of birds/ } \\
\text { treatment }\end{array}$ \\
\hline 1 & $\begin{array}{c}\text { Group-T0: SR with } \\
\text { 100\% normal maize }\end{array}$ & 8 & 4 & 32 \\
\hline 2 & $\begin{array}{c}\text { Group-T1: SR with 50\% } \\
\text { germinated maize }\end{array}$ & 8 & 4 & 32 \\
\hline 3 & $\begin{array}{c}\text { Group-T2: SR with 75\% } \\
\text { germ germinated maize }\end{array}$ & 8 & 4 & 32 \\
\hline 4 & $\begin{array}{c}\text { Group-T3: SR with } \\
100 \% \text { germinated } \\
\text { maize }\end{array}$ & 8 & 4 & 32 \\
\hline
\end{tabular}

Table 1: Experimental design used in the present study.

\section{Results and Discussion}

The present study was undertaken to compare the hematological parameters of Kadaknath birds on diets containing germinated maize@ 50,75 and 100 percent.

As per the results of present study, there was significant increase in all hematological parameters in supplemented groups as compared to control group.
The hemoglobin ( $\mathrm{g} / \mathrm{dl}$ ) ranging from $7.33^{\mathrm{a}} \pm 0.19$ to $9.13^{\mathrm{a}} \pm 0.10$ in group $\mathrm{T} 0,8.18^{\mathrm{b}} \pm 0.05$ to $9.20^{\mathrm{a}} \pm 0.13$ in $\mathrm{T} 1,8.33^{\mathrm{b}} \pm 0.09$ to $9.75^{\mathrm{b}}$ \pm 0.07 in T2 and $8.08^{\mathrm{b}} \pm 0.06$ to $9.15^{\mathrm{a}} \pm 0.10$, total erythrocytes (million $/ \mathrm{mm}^{3}$ ) ranging from $3.40^{\mathrm{a}} \pm 0.08$ to $3.77^{\mathrm{a}} \pm 0.03,3.83^{\mathrm{b}} \pm 0.07$ to $4.15^{\mathrm{b}} \pm 0.04,3.89^{\mathrm{b}} \pm 0.09$ to $4.28^{\mathrm{c}} \pm 0.06$ and $3.79^{\mathrm{b}} \pm 0.02$ to $4.15^{\mathrm{b}}$ \pm 0.02 in $\mathrm{T} 0, \mathrm{~T} 1, \mathrm{~T} 2$ and $\mathrm{T} 3$ groups respectively. Total leucocytes count (thousand/cumm) in $\mathrm{T} 0, \mathrm{~T} 1, \mathrm{~T} 2$ and $\mathrm{T} 3$ groups was ranging from $24.27^{\mathrm{a}} \pm 0.08$ to $23.35^{\mathrm{a}} \pm 0.20,24.53^{\mathrm{a}} \pm 0.14$ to $25.81^{\mathrm{b}} \pm 0.02$, $24.71^{\mathrm{b}} \pm 0.01$ to $26.51^{\mathrm{c}} \pm 0.03$ and $24.35^{\mathrm{a}} \pm 0.03$ to $25.71^{\mathrm{b}} \pm 0.01$, respectively, packed cell volume (\%) ranging from $27.22^{\mathrm{a}} \pm 0.11$ to $30.35^{\mathrm{a}} \pm 0.12$ in $\mathrm{T} 0,29.51^{\mathrm{b}} \pm 0.20$ to $33.46^{\mathrm{b}} \pm 0.12$ in T1, $30.17^{\mathrm{c}} \pm$ 0.12 to $35.5^{\mathrm{c}} \pm 0.22$ in $\mathrm{T} 2$ and $29.27^{\mathrm{b}} \pm 0.17$ to $33.16^{\mathrm{b}} \pm 0.08$ in $\mathrm{T} 3$, respectively. The MCV (femtoliter) was ranging from $75.90^{\mathrm{a}} \pm 0.58$ to79.91 \pm 0.63 in group $\mathrm{T} 0,78.85^{\mathrm{ab}} \pm 1.42$ to $80.92^{\mathrm{ab}} \pm 0.41$ in $\mathrm{T} 1$, $80.26^{\mathrm{b}} \pm 1.42$ to $83.13^{\mathrm{b}} \pm 1.19$ in $\mathrm{T} 2$ and $76.47^{\mathrm{a}} \pm 0.25$ to $80.51^{\mathrm{a}} \pm$ 0.46 in group $\mathrm{T} 3$, respectively. The $\mathrm{MCH}$ (picogram) was ranging from $21.03 \pm 0.14$ to $22.99^{\mathrm{a}} \pm 0.59,21.53 \pm 0.39$ to $22.81^{\mathrm{a}} \pm 0.24$, $21.62 \pm 0.45$ to $24.27^{\mathrm{a}} \pm 0.34$ and $21.10 \pm 0.23$ to $22.29^{\mathrm{a}} \pm 0.11$ in $\mathrm{T} 0$, $\mathrm{T} 1, \mathrm{~T} 2$ and $\mathrm{T} 3$ groups respectively and $\mathrm{MCHC}(\mathrm{g} / \mathrm{dl})$ ranging from $26.90 \pm 0.63$ to $27.45^{\mathrm{a}} \pm 0.28,27.59 \pm 0.24$ to $28.87^{\mathrm{b}} \pm 0.34,27.72 \pm$ 0.09 to $31.13^{\mathrm{c}} \pm 0.14$ and $27.42 \pm 0.17$ to $27.58^{\mathrm{a}} \pm 0.39$ in T0, T1, T2 and $\mathrm{T} 3$ groups, respectively.

The observations of the present study are in close agreement with the findings of Khan., et al. [1], Kwari., et al. [2], Jamre [3] and Gautam [4] but are not in close accordance with the findings of Jain [5], Osman [6], Prajapati [7], Namra., et al. [8] because these workers showed that there was no significant difference found in hematological parameters in their studies.

The increase in all the hematological parameters may be because of germinated maize in feed which may have increased the activity of phytase and other enzymes, which may be capable of releasing of calcium and inorganic phosphorus by its action phytic phosphorus (Bound form of phosphorus) and also increased the energy content. So this inorganic phosphorus readily available for utilization by the body along with increased availability of bivalent ions and trivalent ions like calcium, magnesium, iron and zinc etc. for the growth, necessary for the formation of blood cells, hemoglobin etc. as coenzymes or as their contents, and other metabolic activities of the body.

\section{Conclusion}

From the above observations it is concluded that the inclusion of germinated maize in the diets of Kadaknath layers have significant 


\begin{tabular}{|l|c|c|c|c|c|c|c|c|}
\hline Hb (g/d) & 30 Days & 60 Days & 90 Days & 120 Days & 150 Days & 180 Days & 210 Days & 240 Days \\
\hline T0 & $7.33^{\mathrm{a}} \pm 0.19$ & $7.43^{\mathrm{a}} \pm 0.23$ & $8.13 \pm 0.22$ & $8.48 \pm 0.10$ & $8.65^{\mathrm{a}} \pm 0.07$ & $9.00 \pm 0.09$ & $9.11 \pm 0.09$ & $9.13^{\mathrm{a}} \pm 0.10$ \\
\hline T1 & $8.18^{\mathrm{b}} \pm 0.05$ & $8.20^{\mathrm{b}} \pm 0.11$ & $8.25 \pm 0.07$ & $8.60 \pm 0.13$ & $9.00^{\mathrm{b}} \pm 0.13$ & $9.13 \pm 0.09$ & $9.33 \pm 0.09$ & $9.20^{\mathrm{a}} \pm 0.13$ \\
\hline T2 & $8.33^{\mathrm{b}} \pm 0.09$ & $8.33^{\mathrm{b}} \pm 0.05$ & $8.30 \pm 0.09$ & $8.73 \pm 0.09$ & $9.13^{\mathrm{b}} \pm 0.09$ & $9.18 \pm 0.11$ & $9.43 \pm 0.15$ & $9.75^{\mathrm{b}} \pm 0.07$ \\
\hline T3 & $8.08^{\mathrm{b}} \pm 0.06$ & $7.98^{\mathrm{b}} \pm 0.08$ & $8.20 \pm 0.07$ & $8.55 \pm 0.10$ & $8.80^{\mathrm{a}} \pm 0.11$ & $9.10 \pm 0.07$ & $9.18 \pm 0.19$ & $9.15^{\mathrm{a}} \pm 0.10$ \\
\hline PCV $(\%)$ & $*$ & $*$ & NS & NS & $*$ & NS & NS & $*$ \\
\hline T0 & $27.22^{\mathrm{a}} \pm 0.11$ & $28.34^{\mathrm{a}} \pm 0.18$ & $28.59^{\mathrm{a}} \pm 0.17$ & $28.75^{\mathrm{a}} \pm 0.05$ & $29.20^{\mathrm{a}} \pm 0.03$ & $29.30^{\mathrm{a}} \pm 0.10$ & $29.32^{\mathrm{a}} \pm 0.18$ & $30.35^{\mathrm{a}} \pm 0.12$ \\
\hline T1 & $29.51^{\mathrm{b}} \pm 0.20$ & $31.21^{\mathrm{c}} \pm 0.05$ & $31.57^{\mathrm{b}} \pm 0.23$ & $31.67^{\mathrm{b}} \pm 0.23$ & $32.18^{\mathrm{b}} \pm 0.09$ & $32.32^{\mathrm{b}} \pm 0.10$ & $32.47^{\mathrm{b}} \pm 0.23$ & $33.46^{\mathrm{b}} \pm 0.12$ \\
\hline T2 & $30.17^{\mathrm{c}} \pm 0.12$ & $32.21^{\mathrm{d}} \pm 0.06$ & $33.37^{\mathrm{c}} \pm 0.21$ & $33.56^{\mathrm{c}} \pm 0.14$ & $34.13^{\mathrm{c}} \pm 0.06$ & $34.15^{\mathrm{c}} \pm 0.18$ & $34.36^{\mathrm{c}} \pm 0.18$ & $35.5^{\mathrm{c}} \pm 0.22$ \\
\hline T3 & $29.27^{\mathrm{b}} \pm 0.17$ & $30.52^{\mathrm{c}} \pm 0.20$ & $31.28^{\mathrm{b}} \pm 0.18$ & $31.43^{\mathrm{b}} \pm 0.25$ & $32.15^{\mathrm{b}} \pm 0.08$ & $32.16^{\mathrm{a}} \pm 0.13$ & $32.31^{\mathrm{b}} \pm 0.15$ & $33.16^{\mathrm{b}} \pm 0.08$ \\
\hline & $*$ & $*$ & $*$ & $*$ & $*^{*}$ & $*^{*}$ & $*^{*}$ & $* *$ \\
\hline
\end{tabular}

Table 2: Effect of germinated maize on hematological parameters in Kadaknath after 30 to 240 days of study (Mean \pm SE).

**Shows Significance at $1 \%$ level as compared to control group $(\mathrm{P}<0.01)$.

*Shows Significance at $5 \%$ level as compared to control group $(\mathrm{P}<0.05)$.

The values with the different superscripts in a row are different significantly between groups.

The values with the no superscripts in a row are having no significant relationship.

\begin{tabular}{|c|c|c|c|c|c|c|c|c|}
\hline $\begin{array}{c}\text { TEC (million/ } \\
\mathbf{m m}^{3} \text { ) }\end{array}$ & 30 Days & 60 Days & 90 Days & 120 Days & 150 Days & 180 Days & 210 Days & 240 Days \\
\hline T0 & $3.40^{\mathrm{a}} \pm 0.08$ & $3.59^{\mathrm{a}} \pm 0.08$ & $3.47^{\mathrm{a}} \pm 0.104$ & $3.65^{\mathrm{a}} \pm 0.05$ & $3.68 \pm 0.04$ & $3.68^{\mathrm{a}} \pm 0.04$ & $3.71^{\mathrm{a}} \pm 0.03$ & $3.77^{\mathrm{a}} \pm 0.03$ \\
\hline $\mathrm{T} 1$ & $3.83^{b} \pm 0.07$ & $3.88^{b} \pm 0.03$ & $3.86^{\mathrm{b}} \pm 0.04$ & $3.90^{\mathrm{b}} \pm 0.02$ & $3.93 \pm 0.01$ & $3.93^{b} \pm 0.02$ & $4.03^{b} \pm 0.08$ & $4.15^{\mathrm{b}} \pm 0.04$ \\
\hline $\mathrm{T} 2$ & $3.89^{\mathrm{b}} \pm 0.09$ & $3.91^{\mathrm{d}} \pm 0.06$ & $3.92^{\mathrm{b}} \pm 0.01$ & $3.95^{b} \pm 0.01$ & $3.89 \pm 0.04$ & $4.05^{\mathrm{d}} \pm 0.01$ & $4.08^{\mathrm{b}} \pm 0.05$ & $4.28^{c} \pm 0.06$ \\
\hline T3 & $3.79^{b} \pm 0.02$ & $3.87^{\mathrm{b}} \pm 0.03$ & $3.78^{b} \pm 0.03$ & $3.85^{b} \pm 0.03$ & $3.79 \pm 0.11$ & $3.89^{\mathrm{ab}} \pm 0.05$ & $3.99^{\mathrm{b}} \pm 0.04$ & $4.15^{\mathrm{b}} \pm 0.02$ \\
\hline $\begin{array}{l}\text { TLC (thousand/ } \\
\text { cumm) }\end{array}$ & * & * & $* *$ & * & NS & $*$ & $*$ & * \\
\hline T0 & $24.27^{\mathrm{a}} \pm 0.08$ & $22.40^{\mathrm{a}} \pm 0.05$ & $22.31^{\mathrm{a}} \pm 0.04$ & $22.42^{\mathrm{a}} \pm 0.04$ & $22.58^{\mathrm{a}} \pm 0.05$ & $22.73^{\mathrm{a}} \pm 0.02$ & $23.07^{\mathrm{a}} \pm 0.02$ & $23.35^{\mathrm{a}} \pm 0.20$ \\
\hline $\mathrm{T} 1$ & $24.53^{a} \pm 0.14$ & $25.15^{\mathrm{c}} \pm 0.02$ & $25.21^{\mathrm{c}} \pm 0.04$ & $25.31^{\mathrm{b}} \pm 0.02$ & $25.41^{\mathrm{b}} \pm 0.02$ & $25.51^{\mathrm{b}} \pm 0.02$ & $25.71^{\mathrm{b}} \pm 0.01$ & $25.81^{\mathrm{b}} \pm 0.02$ \\
\hline $\mathrm{T} 2$ & $24.71^{\mathrm{b}} \pm 0.01$ & $25.41^{c} \pm 0.01$ & $25.71^{\mathrm{d}} \pm 0.02$ & $25.81^{c} \pm 0.04$ & $25.58^{b} \pm 0.23$ & $25.99^{c} \pm 0.05$ & $26.16^{c} \pm 0.04$ & $26.51^{c} \pm 0.03$ \\
\hline \multirow[t]{2}{*}{ T3 } & $24.35^{\mathrm{a}} \pm 0.03$ & $24.18^{\mathrm{b}} \pm 0.50$ & $24.10^{\mathrm{b}} \pm 0.04$ & $25.17^{\mathrm{b}} \pm 0.03$ & $25.22^{\mathrm{b}} \pm 0.02$ & $25.15^{\mathrm{b}} \pm 0.24$ & $25.51^{b} \pm 0.02$ & $25.71^{b} \pm 0.01$ \\
\hline & $* *$ & $* *$ & $* *$ & $* *$ & $* *$ & $* *$ & $* *$ & $* *$ \\
\hline
\end{tabular}

Table 3: Effect of germinated maize on hematological parameters in Kadaknath after 30 to 240 days of study (Mean \pm SE).

**Shows Significance at $1 \%$ level as compared to control group $(\mathrm{P}<0.01)$.

*Shows Significance at $5 \%$ level as compared to control group $(\mathrm{P}<0.05)$.

The values with the different superscripts in a row are different significantly between groups.

The values with the no superscripts in a row are having no significant relationship. 


\begin{tabular}{|l|c|c|c|c|c|c|c|c|}
\hline $\begin{array}{c}\text { MCV } \\
\text { (femtoliter) }\end{array}$ & 30 Days & 60 Days & 90 Days & 120 Days & 150 Days & 180 Days & 210 Days & 240 Days \\
\hline T0 & $75.90 \mathrm{a} \pm 0.58$ & $78.82 \mathrm{a} \pm 0.25$ & $78.92 \mathrm{a} \pm 1.06$ & $80.47 \mathrm{a} \pm 0.34$ & $79.38 \mathrm{a} \pm 0.85$ & $79.64 \mathrm{a} \pm 0.81$ & $79.01 \mathrm{a} \pm 0.46$ & $79.91 \mathrm{a} \pm 0.63$ \\
\hline T1 & $78.85 \mathrm{ab} \pm 1.42$ & $79.76 \mathrm{a} \pm 0.16$ & $81.95 \mathrm{~b} \pm 0.22$ & $82.96 \mathrm{~b} \pm 1.96$ & $82.66 \mathrm{~b} \pm 0.91$ & $85.09 \mathrm{~b} \pm 2.44$ & $81.36 \mathrm{ab} \pm 1.29$ & $80.92 \mathrm{ab} \pm 0.41$ \\
\hline T2 & $80.26 \mathrm{~b} \pm 1.42$ & $83.10 \mathrm{~b} \pm 0.67$ & $84.45 \mathrm{c} \pm 0.49$ & $84.91 \mathrm{c} \pm 0.38$ & $85.19 \mathrm{c} \pm 0.52$ & $87.76 \mathrm{c} \pm 0.73$ & $84.45 \mathrm{~b} \pm 0.71$ & $83.13 \mathrm{~b} \pm 1.19$ \\
\hline T3 & $76.47 \mathrm{a} \pm 0.25$ & $79.10 \mathrm{a} \pm 1.71$ & $84.45 \mathrm{c} \pm 0.49$ & $81.31 \mathrm{~b} \pm 0.56$ & $81.99 \mathrm{a} \pm 0.25$ & $82.33 \mathrm{~b} \pm 0.36$ & $79.31 \mathrm{a} \pm 1.05$ & $80.51 \mathrm{a} \pm 0.46$ \\
\hline $\begin{array}{l}\text { MCH } \\
\text { (picogram) }\end{array}$ & $*$ & $*$ & $* *$ & $* *$ & $* *$ & $* *$ & $* *$ & $*$ \\
\hline T0 & $21.03 \pm 0.14$ & $20.38 \pm 0.20$ & $21.03 \mathrm{a} \pm 0.15$ & $21.92 \mathrm{a} \pm 0.38$ & $22.93 \pm 0.32$ & $22.48 \mathrm{a} \pm 0.36$ & $22.17 \pm 0.31$ & $22.99 \mathrm{a} \pm 0.59$ \\
\hline T1 & $21.53 \pm 0.39$ & $21.17 \pm 0.20$ & $21.50 \mathrm{a} \pm 0.03$ & $22.18 \mathrm{a} \pm 0.14$ & $23.52 \pm 0.41$ & $23.45 \mathrm{~b} \pm 0.46$ & $23.15 \pm 0.50$ & $22.81 \mathrm{a} \pm 0.24$ \\
\hline T2 & $21.62 \pm 0.45$ & $21.46 \pm 0.09$ & $23.41 \mathrm{~b} \pm 0.26$ & $23.18 \mathrm{~b} \pm 0.20$ & $23.64 \pm 0.60$ & $24.46 \mathrm{~b} \pm 0.17$ & $24.58 \pm 0.11$ & $24.27 \mathrm{a} \pm 0.34$ \\
\hline T3 & $21.10 \pm 0.23$ & $20.73 \pm 0.89$ & $21.32 \mathrm{a} \pm 0.31$ & $22.08 \pm 0.25$ & $23.64 \pm 0.60$ & $23.19 \mathrm{~b} \pm 0.20$ & $23.11 \pm 0.45$ & $22.29 \mathrm{a} \pm 0.11$ \\
\hline & NS & NS & $* *$ & $*$ & NS & $* *$ & NS & $*$ \\
\hline
\end{tabular}

Table 4: Effect of germinated maize on hematological parameters in Kadaknath after 30 to 240 days of study (Mean \pm SE).

**Shows Significance at $1 \%$ level as compared to control group $(\mathrm{P}<0.01)$.

*Shows Significance at $5 \%$ level as compared to control group $(\mathrm{P}<0.05)$.

The values with the different superscripts in a row are different significantly between groups.

The values with the no superscripts in a row are having no significant relationship.

\begin{tabular}{|c|c|c|c|c|c|c|c|c|}
\hline MCHC (g/d) & 30 Days & 60 Days & 90 Days & 120 Days & 150 Days & 180Days & 210 Days & 240 Days \\
\hline T0 & $26.90 \pm 0.63$ & $25.55 \pm 0.27$ & $24.87^{\mathrm{a}} \pm 0.14$ & $25.99^{\mathrm{a}} \pm 0.19$ & $26.73^{\mathrm{a}} \pm 0.22$ & $26.86^{\mathrm{a}} \pm 0.20$ & $27.43^{\mathrm{a}} \pm 0.38$ & $27.45^{\mathrm{a}} \pm 0.28$ \\
\hline T1 & $27.59 \pm 0.24$ & $26.20 \pm 0.77$ & $26.22^{\mathrm{b}} \pm 0.27$ & $27.21^{\mathrm{b}} \pm 0.26$ & $27.96^{\mathrm{b}} \pm 0.35$ & $28.37^{\mathrm{b}} \pm 0.28$ & $27.90^{\mathrm{a}} \pm 0.14$ & $28.87^{\mathrm{b}} \pm 0.34$ \\
\hline T2 & $27.72 \pm 0.09$ & $26.86 \pm 0.32$ & $28.05^{\mathrm{c}} \pm 0.32$ & $29.28^{\mathrm{c}} \pm 0.45$ & $29.62^{\mathrm{c}} \pm 0.22$ & $30.72^{\mathrm{c}} \pm 0.33$ & $30.15^{\mathrm{b}} \pm 0.33$ & $31.13^{\mathrm{c}} \pm 0.14$ \\
\hline T3 & $27.42 \pm 0.17$ & $25.84 \pm 0.12$ & $26.14^{\mathrm{b}} \pm 0.21$ & $27.15^{\mathrm{b}} \pm 0.25$ & $27.84^{\mathrm{b}} \pm 0.29$ & $28.16^{\mathrm{b}} \pm 0.16$ & $28.25^{\mathrm{ab}} \pm 0.42$ & $27.58^{\mathrm{a}} \pm 0.39$ \\
\hline & NS & NS & $* *$ & $* *$ & $* *$ & $*_{*}^{*}$ & $* *$ & $* *$ \\
\hline
\end{tabular}

Table 5: Effect of germinated maize on hematological parameters in Kadaknath after 30 to 240 days of study (Mean \pm SE).

**Shows Significance at $1 \%$ level as compared to control group $(\mathrm{P}<0.01)$.

*Shows Significance at $5 \%$ level as compared to control group $(\mathrm{P}<0.05)$.

The values with the different superscripts in a row are different significantly between groups.

The values with the no superscripts in a row are having no significant relationship.

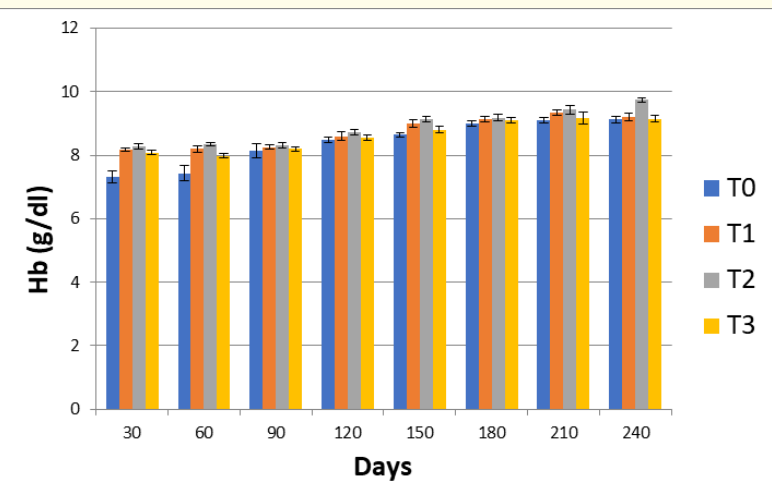

Figure 1: Graph showing effect of germinated maize on $\mathrm{Hb}(\mathrm{g} / \mathrm{dl})$ in Kadaknath.

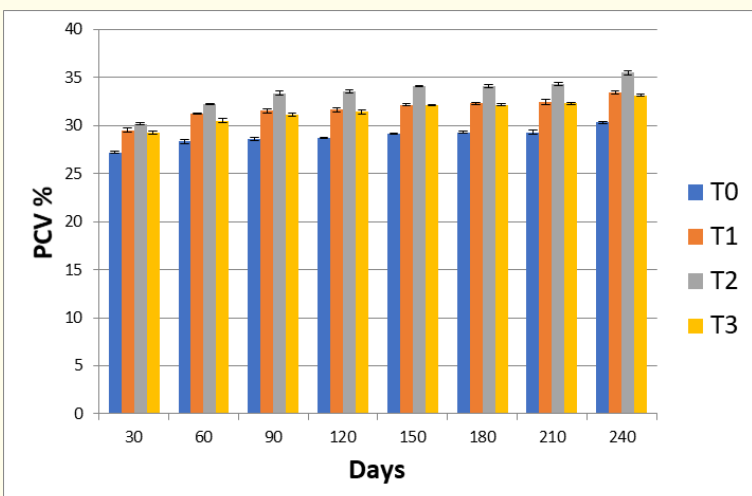

Figure 2: Graph showing effect of germinated maize on PCV (\%) in Kadaknath. 


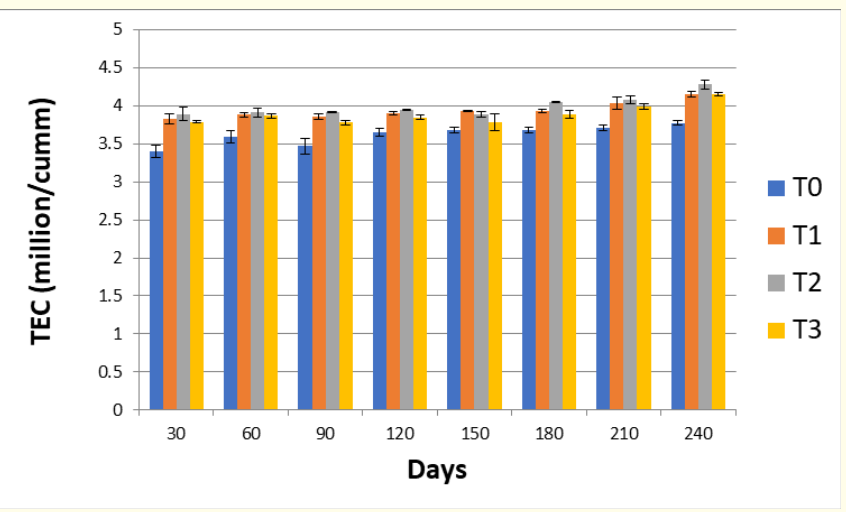

Figure 3: Graph showing effect of germinated maize on TEC (million/cumm) in Kadaknath.

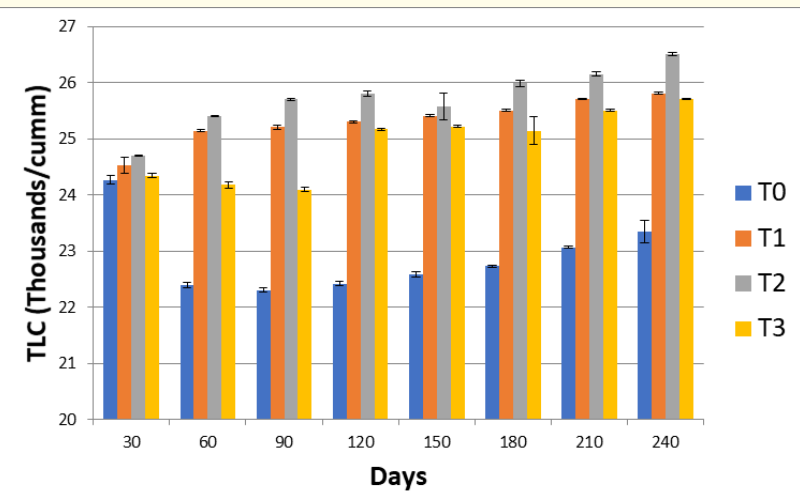

Figure 4: Graph showing effect of germinated maize on TLC (Thousand/cumm) in Kadaknath.

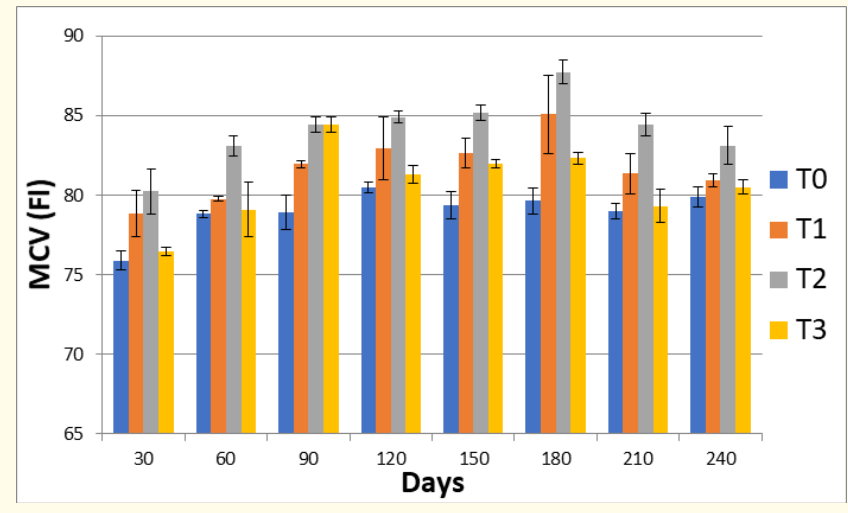

Figure 5: Graph showing effect of germinated maize on MCV (fl) in Kadaknath.

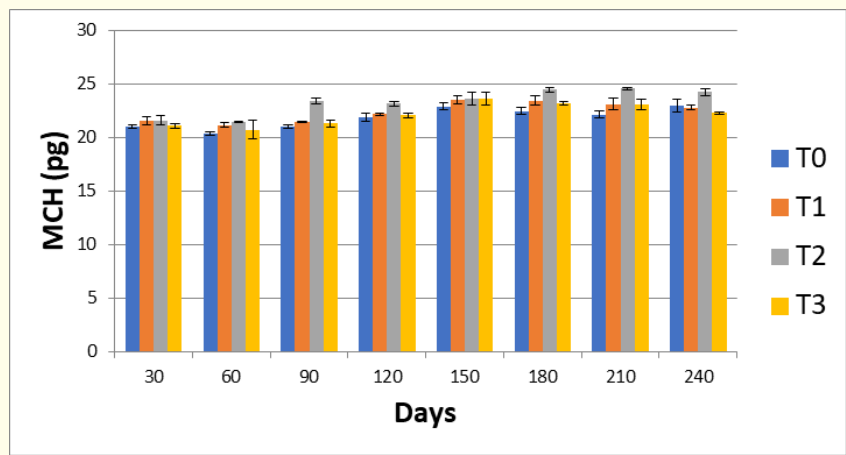

Figure 6: Graph showing effect of germinated maize on MCH (pg) in Kadaknath.

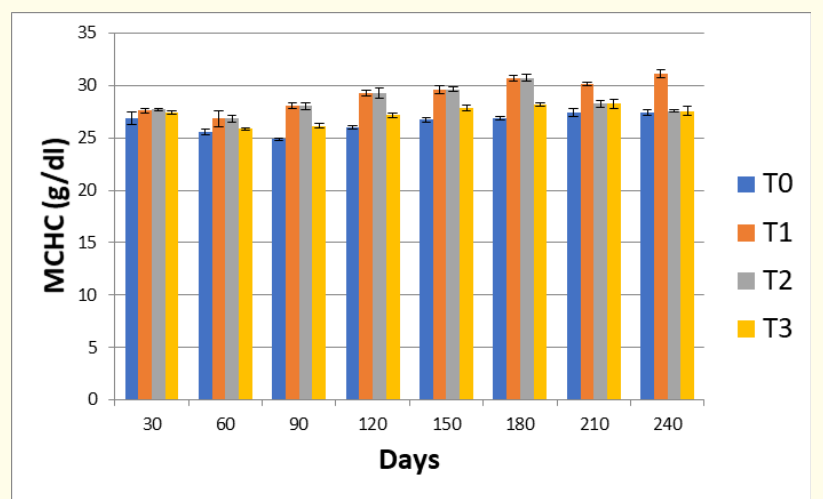

Figure 7: Graph showing effect of germinated maize on MCHC (g/dl) in Kadaknath.

increase in all the hematological parameters when the germinated maize has been included at the rate of 50 and $75 \%$ as compared to $100 \%$ germinated maize diets.

\section{Bibliography}

1. Khan MA., et al. "Effect of germinated maize and sorghum based diet at different levels on haematological parameters in kadaknath". Global Journal of Bio-science and Biotechnology 6.3 (2017a): 482-485.

2. Kwari ID., et al. "Replacement value of low tannin Sorghum (Sorghum bicolor) for maize in Broiler chickens diet in the semi arid zone of Nigeria". International Journal Poultry Science 11 (2012): 333-337. 
3. Jamre B. "Evalution of diet containing germinated maize and multienzyme complex on growth and production performance of broilers". M.V.Sc and A.H.Thesis. (Veterinary Physiology), Nanaji Deshmukh Veterinary Science University, Jabalpur (M.P) (2005).

4. Gautam M. "Comparative studies on growth and production performance of broilers on diets containing germinated sorghum and multienzyme complex". M.V.Sc and A.H. Thesis (Veterinary Physiology), Nanaji Deshmukh Veterinary Science University, Jabalpur (M.P) (2015).

5. Jain A. "Biochemical and haematological parameters in broilers”. Indian Journal Animal Nutrition 25.3 (2008): 285-287.

6. Osman AHE. "Effect of multi enzyme supplementation and grain source on broiler performance and carcass quality". Animal Production Science and Technology 70 (2009): 28-29.

7. Prajapati RS. "Studies on phytase supplementation on growth performance and haemato-biochemical parameters in broilers". M.V.Sc and A.H. Thesis (Veterinary Physiology), Rajmata Vijayaraje Scindia Krishi Vishwa Vidyalaya Gwalior (2010).

8. Namra MMM., et al. "Substitute yellow corn with sorghum in starter and grower diets of fayoumi chicks". Egypt Poultry Science 22 (2011): 39-49.

\section{Assets from publication with us}

- Prompt Acknowledgement after receiving the article

- Thorough Double blinded peer review

- Rapid Publication

- Issue of Publication Certificate

- High visibility of your Published work

Website: www.actascientific.com/

Submit Article: www.actascientific.com/submission.php Email us: editor@actascientific.com

Contact us: +919182824667 